ISSN: 1838-3815 (online) Journal Homepage: https://ojs.deakin.edu.au/index.php/itlge/

\title{
Relevance of selected social science degree programs on skills development and graduate employability in Zambia
}

\author{
Kapambwe Mwelwa ${ }^{1}$, Lazarus D.M. Lebeloane ${ }^{2}$ and Ailwei S. Mawela ${ }^{3}$ \\ Corresponding author: Kapambwe Mwelwa (kmwelwa@unza.zm ) \\ ${ }^{1}$ School of Education, Department of Educational Administration and Policy Studies, University of Zambia, \\ https://orcid.org/0000-0002-5878-3971 \\ ${ }^{2}$ College of Education, Department of Science and Technology University of South Africa, Pretoria, South Africa, \\ https://orcid.org/0000-0002-5498-0118 \\ ${ }^{3}$ College of Education, Department: Curriculum and Instructional Studies University of South Africa, Pretoria, \\ South Africa, https://orcid.org/0000-0002-7043-8716
}

\begin{abstract}
A pragmatic approach was used to explore the extent to which four selected social science degree programs were relevant for the skill needs of the job market in Zambia. Both qualitative and quantitative data were collected from 162 participants using interviews and questionnaires. The SPSS version 24 and Atlas. Ti Version 8 were used to analyse and interpret data within the framework of the Capability Approach. The findings reveal that the relevance of each of the four social science degree programs depend on how key stakeholders in higher education and the labour market perceive them and that graduate employability was affected by factors such as the need and importance of social sciences to the labour market; employer and student perceptions of employability skills in the degree programs; demand for the programs; graduate work readiness, and the availability of graduate job prospects. It could be concluded that although all four social science degree programs were important, their relevance to the needs of Zambia's labour market varied from program to program.
\end{abstract}

Keywords: social science degree programs, skills development, graduate employability, labour market, Zambia

\section{Introduction}

Zambia is a landlocked country in Southern Africa with an estimated population of 18 million people (Zambia Statistical Agency, 2019). The majority of the population lives in the rural parts of the country. Agriculture, mining, construction, and manufacturing are the main economic stay of the country. In 2019, Zambia had 60 registered universities, of which six were public and 54 were privately run. The higher education sector in Zambia is guided by the policy objective of enhancing the quality and relevance of higher education provision and the career development support to all students (MOHE, 2019). These objectives speak to Zambia's long-term vision of becoming a middle-income country by the year 2030 (GRZ, 2006) through enhanced human capital development. In 2019, over 95,000 students were enrolled in both public and private universities at the bachelor level (Simukanga et al., 2020). There were more students enrolled in social science degree programs compared to those in STEM programs. The 2014-2018 graduation trends show that on average there were 3500 graduates 
from social science degree programs each year. Most graduates from social science degree programs found employment opportunities in the private sector and a few in the public service.

However, studies have revealed that most higher learning institutions in Zambia were not equipping graduates with relevant skills for the labour market (Moono \& Rankin, 2013; United Nations Development Program, 2016). Furthermore, the production of more university graduates in social sciences than those in science, technology, engineering and mathematics (STEM) programs (Ministry of Education, 2017; Simukanga et al., 2020) has been at variance with developmental priorities and the realities of the labour market and the nation in which STEM skills are in short supply. (UNDP, 2016). The mismatch in skills contributed greatly to the increased number of unemployed graduates (Moono \& Rankin, 2013). Zambia's graduate unemployment rate stood at $12.5 \%$ in 2019 (Zambia Statistical Agency, 2019). Youth unemployment also increased from 11.4\% in 2018 to $17.9 \%$ in 2019 (Zambia Statistical Agency, 2019). These statistics confirm the increasing unemployment rate of Zambia's youth and graduates. Several measures were attempted (Government of the Republic of Zambia, 2015) to realign the skills mismatch challenge between higher education graduates and the labour market expectations to overcome youth and graduate unemployment. This challenge, however, seems to be far from ending (Bhorat et al., 2015) and is exacerbated by the weak partnerships between higher education institutions and the labour market in Zambia (UNDP, 2016).

While a lot has been written on how skills development could be used to promote graduate employability and productivity in the labour market (Oppong \& Sachs, 2014; Jackson, 2015), only a few empirical studies had been conducted in the Zambian context (Mulenga, 2015). Most studies conducted on skills development focused on Technical Education, Vocation and Entrepreneurship Training (TEVET), and STEM programs and not social sciences (Simukungwe-Moono, 2010; Mwila, 2017). This is despite there being more social science graduates compared to other study areas. In response to this situation, this study reported in this paper, explored the extent to which social science degree programs in selected Zambian universities were relevant to the skills needs in the nation's labour market. Following the aims of the study, there is a review of the related scholarly literature and an outline of the methodology and theoretical framework. The results of the study are then presented and discussed before the concluding remarks and implications of the study.

\section{Aims of the study}

This study aimed to explore the extent to which the four social science degree programs from the selected universities were relevant to the skills needs of the labour market in Zambia and thereby likely to promote graduate employability.

Specifically, the study aimed to:

1. Ascertain the relevance of the four social science degree programs from the selected universities to the skill needs of the job market in Zambia.

2. Determine what constituted graduate employability in the four social science degree programs from the selected universities in Zambia.

The literature review which follows explores literature relevant to the study of skills development and graduate employability in social science degree programs. It provides insight into the discourse of what constitutes skills development and graduate employability.

\section{Literature review}

\section{Conceptual understanding of social sciences, graduate employability, and employability skills development}

Social sciences are study areas that deal with the study of human relations. In this paper social sciences refers to programs of study which may be arts, humanities, and indeed social science degree programs 
offered at the universities (Anwaruddin, 2013). These programs include Bachelor degrees in Social Work, Development Studies, Public Administration, Political Science, Economics, Sociology, and others. Social sciences also include education-related degree programs such as the Bachelor of Education in Social Sciences and others. Skills, on the other hand, refer to the possession of knowledge, attributes, and competencies by any graduate from a degree program to execute defined work opportunities to the satisfaction of the employer and themselves. These skills can either be technical (job-specific) or generic (soft) skills. Generic skills, also known as employability skills are said to increase opportunities to be employable (Cunningham \& Villasenõr, 2016). Generic skills are valuable because they promote critical thinking, innovation, and knowledge generation (Kinash, Crane, \& Judd, 2016). Employability skills can help one to analyse, think and understand complex issues to solve work-related obstacles and achieve predetermined goals. Apart from the disciplinary knowledge, many emphasise the need for employability skills to be embedded in non-technical degree programs such as social sciences in the university curricular (Cunningham \& Villasenõr, 2016).

Though they are not job-specific, generic (employability) skills are also professional skills that can render a graduate more efficacious in the application of disciplinary knowledge in any given work environment. There are several employability skills that graduates from any degree program must acquire and develop. Some of the employability skills include effective communication, interpersonal skills, critical thinking, self-awareness, ability to use ICT to analyse data, problem-solving skills, creativity, being enterprising, professionalism, and self-management to mention but a few (Riebe \& Jackson, 2014). Riebe and Jackson, (2014) argue that graduates who possess the said skills tend to have the capacity to work and collaborate with other individuals without challenges. Subsequently, being employable entails, a graduate being fit to take up a career and not necessarily a job guarantee (Kinash et al., 2016). It is about the effective use of the acquired skills, attributes, knowledge, individual agency, and the prevailing labour conditions to create, maintain, and secure employment opportunities after they graduate from a university (Damao, Peprah, \& Brefo, 2021). The development of employability skills thus entails exposure of graduating students to the different education and training processes in universities to acquire and develop competencies and personal attributes necessary to engage in self or wage employment in the labour market.

\section{The relevance of social sciences to the labour sector skill needs}

Many studies have been conducted to establish the relevance of social science degree programs to the skill needs of the labour market in the $21^{\text {st }}$ Century (Osmani, Weerakody, Hindi, \& Eldabi, 2019). The relevance of any degree program can be established from its usefulness in the employment industry and other spheres of life. It is important for skills acquired during university studies to match the skill needs of the labour industry (Igwe et al., 2020). Any variance may lead to a skills mismatch, thereby rendering the acquired qualification irrelevant (Rastrick, 2018). Many social science degree programs, unlike natural sciences, do not have a specific relationship with people's career pathways. They are thus referred to as 'generalist' programs (Kinash et al., 2016). It is this uncertainty with what one would become upon graduation that makes potential employers from the labour industry doubt the capabilities of such graduates from social sciences. It is perceived that this makes graduate employability, in the context of these programs uncertain, especially in an economy where skills from STEM programs were in greater demand than those from social sciences. More so, graduates from the so-called 'generalist' social science degree programs may experience challenges in demonstrating the acquired skills and what they are capable of accomplishing within an organisation compared to those with STEM qualifications (Clarke 2018b; Rastrick, 2018:). It must, however, be noted that social science degree programs are fundamentally important to the understanding of society and social cohesion.

\section{Labour market skill needs}

Most organizations globally seem to be interested in the services of STEM graduates compared to Social Science graduates (Axelrod, 2017; Yonezawa, 2017). Several examples point to the decline in 
the influence of social science degree programs in some higher educational institutions. In some instances, the relevance of universities and faculties offering social science degree programs has been questioned and criticised to the point of closing down (Anwaruddin, 2013). The indirect rationale for this development stems from the negative perspective regarding the relevance of social sciences towards economic transformation and graduate employability (Elkhayat, 2018). Today, university education is driven by the focus on market-oriented programs such as Business, ICT, and Engineering. Furthermore, investment in STEM university programs is highly regarded as the only sure way through which the national economies can be transformed the world over (Yonezawa, 2017; Simukanga et al., 2020). Given these circumstances, there is a need for a clear understanding of the kinds of skills graduates obtain from social science degree programs and to ascertain the extent to which such skills influence their employability in Zambia within the framework of the capability approach.

\section{Theoretical framework}

Using the Capability Approach, the study explored the extent to which the social science degree programs were relevant in promoting skills development and graduate employability in Zambia (Menashy, 2014, p. 19). Premised on the supposition that individuals must be afforded opportunities and freedoms for them to be empowered with skills, knowledge, and agency to enjoy the life they value, the Capability Approach was appropriately used to explore the extent to which each of the four social science degree programs empowered the graduating students with employability skills, freedoms, and the agency to acquire the employability status and identity to pursue opportunities they valued (Jackson, 2016). Some relevant concepts and characteristics of the human capital theory (Akinyemi, 2013), and the screening hypothesis (James, Warhurst, Tholen, \& Commander, 2013) were also used as part of the theoretical framework in answering the question of the relevance of social science degree programs in the context of skills development and graduate employability in Zambia.

\section{Methodology and approach}

Within the context of the pragmatic philosophical paradigm, the convergent parallel mixed-methods design was adopted for use in the paper (Creswell \& Plano Clark, 2007; Creswell, 2014). The pragmatic paradigm was adopted as it allowed for both the subjectivity of the researchers' reflection on the research problem as well as their objectivity in the collection and analysis of data (Morgan, 2007; Creswell, 2014). This removed the notion of incompatibility in the use of the mixed methods approach in the inquiry (Teddlie \& Tashakkorri, 2009; Legg \& Christopher, 2021) to practically and logically meet the objectives of the study.

A total of 162 respondents participated in the study. Of the participants, 77 were males and 85 females. The study participants included: Eight key informants, 22 employers, 12 lecturers, and 120 graduating students. In terms of the levels of education, the non-student respondents had qualifications ranging from diploma certificates to doctoral degrees. The probability and nonprobability sampling techniques were used to select the study participants. All participants, with the exception of the students, were purposively selected in the study due to the lack of a complete sampling list to draw them randomly.

120 Students were randomly selected for the study using simple random sampling techniques. The course lists for registered final year students in the social science degree programs constituted the sampling frame from which students were randomly selected to take part in the study. Using the simple random sampling technique, 120 students were selected into the study sample using the sampling interval of five from an estimated population of 600 students pursuing the selected social science degree programs from the five universities. Eight Key informants, 22 employers, and 12 lecturers were all purposively selected. The key informants were selected from the Ministry of Higher Education, Higher Education Authority, Ministry of Labour and Social Security, Zambia Federation of Employers, Zambia Congress of Trade Unions, and deans and heads of departments from the selected 
public and private universities. The 22 employers were drawn from government departments, quasigovernment institutions, non-governmental organisations, and other local and international business organisations and companies. Purposive sampling was used to select 12 Lecturers who taught on either the Bachelor of Social Work, Bachelor of Development Studies, Bachelor of Public Administration, or Bachelor of Education (Social Science) from different universities to partake in the study. Five universities participated in the study. Two were public and three were private universities. The universities were located in three different provinces of Zambia.

The study used semi-structured questionnaires and semi-structured interview guides for data collection. The student questionnaire was pre-test piloted on students who were not part of the study. The results of the pilot test informed the revisions to the structure and clarity of questions. In using a self-administered semi-structured questionnaire, the students and employer had to rate their levels of satisfaction with the employability skills of final-year students pursuing social science degree programs on a Likert scale of 1 to 5 (1. Very Dissatisfied, 2. Dissatisfied, 3. Neither, 4. Satisfied, and 5. Very Satisfied) (refer to Table 1.1). The methodology and questionnaire design were informed by previous studies conducted on skills development and graduate employability in different regions (Riebe \& Jackson, 2014; Gao, Wang, \& Cui, 2014; Finch, Hamilton, Riley, \& Zehner, 2013; Flash Eurobarometer, 2010).

Quantitative data from self-administered semi-structured questionnaires were analysed using the Statistical Package for Social Scientists (SPSS) Version 22 to generate the descriptive statistics in the form of charts, tables, and graphs (Bryman, 2008; Onwuegbuzie \& Combs, 2011). Bivariate and Multivariate Statistical tests and analyses were run to compare and test the significance of findings on different variables regarding the relevance of social science degree programs (Field, 2013). Qualitative data were analysed using ATLAS.TI Version 8 software to generate common themes from the given responses. The analysed qualitative and quantitative data were interpreted concurrently and converged at the interpretation stage. Quantitative data were subjected to reliability and validity tests (Cohen, Manion, \& Morrison, 2010). For instance, the questionnaires were also subjected to a reliability test using the Alpha Cronbach test in SPSS after data collection and were found reliable (Tavakol \& Dennick, 2011). The constructs in the student, employer, and lecturer questionnaires revealed high Alpha Cronbach values. The Alpha Cronbach reliability test results for the constructs in the three questionnaires were .738 for the lecturer questionnaire; .899 for the employer questionnaire, and .899 for the student questionnaire. On the other hand, trustworthiness was used to confirm the authenticity and credibility of the collected qualitative data. Trustworthiness (Shenton, 2004) was employed to help the researchers survey the credibility and rigour of the study's qualitative findings. It was ensured that credibility, dependability, transferability, and confirmability of the findings were achieved (Bless, Higson-Smith, \& Sithole, 2013) to enhance the scientific rigour of qualitative findings.

Lastly, ethical issues relating to the goal of the study, confidentiality, anonymity, permission to research staff members of different institutions, the privacy of participants, and the use of collected data were considered and adhered to (Bless et al., 2013). As proof of adherence to the ethical requirements, this paper emanated from the study conducted under the University of South Africa Ethical Approval Certificate number 2019/05/15/64027848/18/MC (UNISA Policy on Research Ethics, 2016).

\section{Results}

Considering the relevance of the four social science degree programs from the selected universities to the skill needs of the job market in Zambia, two themes emerged from the data. The themes were identified as the most common responses that emerged from the analysis of the collected qualitative and quantitative data on the relevance of the programs. These were the need and importance of social sciences to industry, and the demand for the social science programs as presented below. 
Respondents expressed different views about the value of Social Work, Development Studies, Public Administration, and Education (social science) degree programs. Most key informants however submitted that social sciences degree programs were relevant to the current needs of the labour market and society. For example, when asked if social sciences were relevant, one respondent said:

No, I don't think social sciences are irrelevant, these are human sciences, they teach us human morality, human decency, and so forth, and so on. It is just the way the world has become, but I think to deny their intrinsic importance would be yielding to a very dangerous cynicism. It is just that the world is in a state of flux, it is very easy to cynically just say shut them down. (P\#06: Dean of Faculty)

However, when respondent $\mathrm{P} \# 04$ was asked about the importance of producing more social scientists for the labour industry in comparison to those with STEM qualifications, she took into consideration the magnitude of the Zambian economy and described social sciences as only playing a supportive role to physical sciences on the labour market by stating that:

But the only problem is it's the balance. If our economy is big, believe me, even the ones that we are producing were not going to be enough. By economy I mean if our industry was big enough to absorb. The problem is we have no business. It's like you are producing people who are not the core business.... the support, these are the support system because social scientists are the support system. The industry is driven by these pure science people.... (P\#04: Higher Education Department)

\section{Demand for the social science degree programs}

Findings showed that the demand for social science degree programs had not increased in the previous three years. That was endorsed by most respondents in whose universities social science degrees were offered. For example, one participant, in responding to the question on students' input and output in Social Work, said:

For Social Work from 2010, the number increased I think, the average number should be between 50 and 100, at some point we even had 150 when the government was sponsoring. Because [we] realised that social work was on-demand, so even in terms of the quota allocation, Social Work was given attention, so we had between 120 to 150 [students] per academic year, but the numbers reduced from 2018 because of the [lack of] sponsorship from the government. (P\#07: Head of Faculty Department)

A university employee responded to the question on student numbers in a social science degree program in this way:

Each year we get about, 30, 45, but the number has been going down because there has been a realisation that they don't get jobs, you see. However, those who are, already employed find it easier. (P\#05: Dean of Faculty)

Upon inquiring about the number of Development Studies students who graduated in the previous two years at one university, one respondent said:

The range of graduates differs, but initially, when we started, the number has been changing or fluctuating due to the mushrooming of universities across the country. But on average we have graduated 150. (P\#06: Head of Faculty Department)

Generally, the key respondents were of the view that social science degree programs were important, albeit with fluctuations in the demand for the programs by prospective students.

In determining what constituted graduate employability in the four social science degree programs from the selected universities in Zambia, three themes emerged as key in promoting employability: 
employer and student perception of employability skills; graduate work readiness; and prospects of job availability.

\section{Employer and student perceptions of employability skills}

It was also revealed from the study that the extent to which the students and various stakeholders in the labour industry perceived the employability skills developed from the social science degree programs had a bearing on the relevance of graduates to the employability discourse. It emerged that students were satisfied with the seven employability skills (with a mean score closer to 4.0) and very satisfied with their accountability skills (with a mean score of 4.5). On the other hand, employers were satisfied with social science graduates' professionalism, problem-solving, and self-management skills. With a mean-score nearing 4.0. They were however closer to neutral when it came to their satisfaction with other skills such as graduates' interpersonal skills, creativity, accountability, and the carrying out of tasks in well-defined settings as shown in Table 1.

Table 1: Student and Employer Perception of Employability Skills

\begin{tabular}{|l|c|c|c|c|}
\hline & \multicolumn{2}{|c|}{ STUDENT } & \multicolumn{2}{c|}{ EMPLOYER } \\
\hline EMPLOYABILITY SKILLS & MEAN & $\begin{array}{c}\text { STD. } \\
\text { DEVIATION }\end{array}$ & MEAN & $\begin{array}{c}\text { STD. } \\
\text { DEVIATION }\end{array}$ \\
\hline Professionalism & 4.4 & 0.71 & 3.5 & 0.70 \\
\hline $\begin{array}{l}\text { Ability to perform tasks in a defined } \\
\text { setting }\end{array}$ & 4.4 & 0.68 & 3.3 & 0.76 \\
\hline Critical Thinking & 4.3 & 0.65 & 3.4 & 0.65 \\
\hline Problem Solving & 4.2 & 0.80 & 3.6 & 0.60 \\
\hline Interpersonal Skills & 4.4 & 0.78 & 3.2 & 0.79 \\
\hline Accountability & 4.5 & 0.73 & 3.3 & 0.78 \\
\hline Creativity and Initiative Skills & 4.3 & 0.80 & 3.3 & 0.73 \\
\hline Self-Management & 4.4 & 0.74 & 3.5 & 0.68 \\
\hline
\end{tabular}

Source: Author, 2020

Besides, the qualitative data showed that interdisciplinary skills, transferable skills, analytical skills, innovativeness, problem-solving skills, adaptability skills, and specialised disciplinary knowledge were central to a graduate's employability. That was endorsed by one respondent who said:

So generic skills for me need to be embedded and what we need to start doing is to think of striking a balance between disciplinary education which is extremely important and also skills education. You see, the thing is I think there's been an evolution in terms of the purposes of education. We are no longer in that space where it's learning just for curiosity, as you mentioned, it's learning also for employability, learning also to be part of the solutions to some of the challenges we are having. (P\#03: Higher Education Regulatory Agency)

Another respondent highlighted the importance of analytical, creativity, innovativeness, and entrepreneurial skills for graduates in social sciences to be employable by saying:

There are several skills which social science students should possess. Of course, being university graduates they are supposed to have excellent analytical skills. So apart from analytical skills, they also need to be highly innovative.... You know even interpersonal skills which are very key as they relate to a multicultural environment ... And then they also need to have some entrepreneurship skills because you know most of the courses in the social sciences were designed for someone to work in the public sector and the public sector as an employee. (P\#08: Labour Department)

Upon inquiring further on the skills needed for graduates to be employable, another respondent said:

Mwelwa, K., Lebeloane, L.D.M., \& Mawela, A.S. (2021). Relevance of Selected Social Science Degree Programs on Skills Development and 
...the need for interdisciplinarity is critical when you consider some of the things that you will face today that need interdisciplinary skills. (P\#08: Labour Department)

\section{Graduate work readiness}

The extent to which social sciences graduates were perceived to be work-ready with their first employer was considered critical in influencing their employability. Cross-tabulations were thus done with a focus on students' ages, gender, and the degrees they were enrolled for to determine their levels of work readiness as graduating students in the four social science degree programs (refer to Table 2). A chi-square independence test was carried out to further determine the significance of the association between work readiness and age, students' gender, and the programs of study. The test results indicated that $35+$ years old students were $91 \%$ more likely to be work-ready compared to the $15-24(77 \%)$ years old and the $25-34(69 \%)$ years old. This association of variables was however insignificant $(p>0.05)$. This could imply that there were other important discrete variables apart from age, which influenced graduating student's work readiness in the target population.

There was an insignificant association ( $p>0.05$ ) between gender and program of study as well as the work readiness of final year university students in selected universities. This could imply that gender was not the main factor in determining work readiness for graduating students in the four social science degree programs in the target population.

Table 2: Bivariate Associations between Selected Background Characteristics and Work Readiness

\begin{tabular}{|l|c|c|}
\hline \multicolumn{1}{|c|}{ CHARACTERISTICS } & \multicolumn{2}{c|}{ WORK-READINESS } \\
\hline Age & 23.2 & Yes \\
\hline $15-24$ & 30.8 & 76.8 \\
\hline $25-34$ & 9.1 & 69.2 \\
\hline $35+$ & & 90.9 \\
\hline P=0.315 & & \\
\hline Gender & 24 & 76 \\
\hline Male & 26 & 74 \\
\hline Female & & \\
\hline P=0.502 & 100 & 85.7 \\
\hline Program of Study & 14.3 & 84.6 \\
\hline Bachelor of Arts in Public Administration & 15.4 & 71.6 \\
\hline Bachelor of Arts in Development Studies & 28.4 & 66.7 \\
\hline Bachelor of Arts in Social Work & 33.3 & \\
\hline Bachelor of Education & & \\
\hline P=0.488 & & \\
\hline
\end{tabular}

\section{Significance level 0.05}

Source: Author, 2020

Furthermore, a Multivariate Logistic Regression Analysis was conducted to ascertain graduating students' work-readiness and selected background characteristics, namely, Age, Gender, Marital Status, and Program of Study (refer to Table 3). It emerged that students aged 35+ years were 3 times more likely to be ready for work compared to those aged 15-24 years. Students aged $25-34$ were $36 \%$ less work-ready. Findings further showed that female students were $28 \%$ less likely to be ready for work compared to their male counterparts. Married students (28\%) were more likely to be ready for work compared to unmarried. Table 3 indicates that students studying development studies were more likely to be work-ready than those studying Public Administration, Social Work, and Education. The results on multivariate logistic regression revealed that the selected characteristics (age, gender, 
and programs of study) of the student background were not significant predictors of their work readiness.

In expressing views on the work-readiness of most graduates, employers indicated that most were not ready. Upon inquiring whether those with social science degrees were work-ready at job entry-level, one said:

There is a big problem with regards to quality and the competence of the graduates, right from the university level up to colleges. Some gaps have been noted, ... and these gaps do not only lie in the social sciences which are the subject matter but even in the physical sciences themselves.... (P\#02: Employers' Federation)

The respondent further stated:

... regardless of what field, regardless of what qualification, what profession, when they employ someone from university or college mostly, they have to retrain them for some time before they become productive. (P\#02: Employers' Federation)

Table 3: Multivariate Logistic Regression between Work-Readiness of the Student and Selected Background Characteristics

\begin{tabular}{|l|c|c|c|c|}
\hline \multicolumn{1}{|c|}{ WORK READINESS } & ODDS RATIO & P-VALUE & \multicolumn{2}{c|}{ 95\% CONFIDENCE INTERVAL } \\
\hline Age & & & & \\
\hline $15-24$ & Ref & & & \\
\hline $25-34$ & 0.64 & 0.38 & 0.24 & 1.74 \\
\hline $35+$ & 3.04 & 0.36 & 0.20 & 33.50 \\
\hline Sex & & & & \\
\hline Male & Ref & & & \\
\hline Female & 0.72 & 0.51 & 0.27 & 1.91 \\
\hline Marital Status & & & & \\
\hline Single & Ref & & & \\
\hline Married & 1.28 & 0.79 & 0.21 & 7.76 \\
\hline Program of Study & & & & \\
\hline $\begin{array}{l}\text { Bachelor of Arts Development } \\
\text { Studies }\end{array}$ & Ref & & & \\
\hline $\begin{array}{l}\text { Bachelor of Arts Public } \\
\text { Administration }\end{array}$ & 0.82 & 0.88 & 0.06 & 9.79 \\
\hline Bachelor of Education & 0.29 & 0.26 & 0.03 & 2.48 \\
\hline Bachelor of Social Work & 0.50 & 0.26 & 0.15 & 1.69 \\
\hline
\end{tabular}

Source: Author, 2020

\section{Availability of Job Prospects}

The availability of job prospects for social science degree graduates was found to be another important factor in determining the relevance of those degree programs in the labour market considering that most graduates were interested in seeking employment after graduating. Findings indicated that more females $(69 \%)$ than males $(60 \%)$ wished to be employed after graduating. More males $(31 \%)$ than females (13\%) wished to be self-employed after graduating. The findings further indicated that more female students $(19 \%)$ than males $(8 \%)$ were willing to study further after graduating. These findings show a significant $(p<0.05)$ relationship between gender and goal after graduation $(\mathrm{P}=0.029)$. It further emerged that majority of the students $(83 \%)$ pursuing the Bachelor of Education (social science) degree had the goal of getting employed after graduation compared to those in other social science programs (refer to Table 4). 
Table 4: Bivariate Association between Program of Study and Goal after Completion

\begin{tabular}{|l|c|c|c|}
\hline \multicolumn{1}{|c|}{ PROGRAM OF STUDY } & $\begin{array}{c}\text { SEEK } \\
\text { EMPLOYMENT }\end{array}$ & $\begin{array}{c}\text { SELF- } \\
\text { EMPLOYMENT }\end{array}$ & $\begin{array}{c}\text { PURSUE FURTHER } \\
\text { STUDIES }\end{array}$ \\
\hline $\begin{array}{l}\text { Bachelor of Arts in Development } \\
\text { Studies }\end{array}$ & 70.8 & 8.3 & 20.8 \\
\hline $\begin{array}{l}\text { Bachelor of Arts in Public } \\
\text { Administration }\end{array}$ & 42.9 & 14.3 & 42.9 \\
\hline Bachelor of Education & 83.3 & 16.7 & 0 \\
\hline Bachelor Arts with Social Work & 64.2 & 24.7 & 11.1 \\
\hline
\end{tabular}

$\mathbf{P}=\mathbf{0 . 1 3 9}$

Source: Author, 2020

It emerged from the quantitative analysis that $25 \%$ of the students pursuing Social Work were going to become self-employed compared to those studying Development Studies (8\%). Besides, $43 \%$ of the students pursuing Public Administration desired to further their studies after completion of the initial degree. More so, the association between the degree and desired goal after completion was insignificant ( $p>0.05)$.

Mixed views were expressed by those interviewed from the labour market and universities on the relevance of social science degree programs in the labour market skill needs and job prospects. One respondent from a university said:

All our graduates who have left our university, have immediately been deployed. So far, we have not heard of anyone who has graduated waiting for two years on looking for employment. And those who haven't been deployed have immediately gone into upgrading their qualification to masters. ... But also, the economy is not growing at the rate at which maybe graduates are being produced into the economy. So much as these are relevant, they are not absorbing them because it's not growing. (P\#05: Dean of Faculty)

Another respondent answered the same question in this way:

For the Bachelor of Social Work, you see that it is offered by different universities at the moment in Zambia because it is something on demand. Students are needed in various industry sectors. You find social workers, working in the mines, you find them in hospitals. So, you find they are needed by government in their ministry's departments, UN agencies, NonGovernmental Organisations, Community Based Organisations, Faith-Based Organisations and, some would just want to venture in business and the like. But the job prospects are there - it is a program which is demand-driven. It is a generic program because we prepare them to fit into different sectors. (P\#07: Head of Faculty Department)

In responding to the outlook of social science degree graduates' job prospects, one respondent said:

... there is that challenge but coming to Social Sciences, we have been producing quite a lot. But the reality of the day is that there are not many jobs out there. Basically, as a country, we have not created enough jobs especially outside the public sector and this is telling by the numbers of graduates that are unemployed and so forth. The question is whether this points to a mismatch between education and skills out there. It is a question that we can't answer outrightly because it's complex.... (P\#03: Higher Education Regulatory Agency).

\section{Discussion}

The results of this study are discussed around the themes that emerged from the empirical research. The first objective addressed the relevance of the four social science degree programs from the selected universities to the skill needs of the job market in Zambia. The importance and need for social 
sciences and the demand for social science degree programs in selected universities emerged as key themes from the data.

\section{Importance and need for social sciences}

It emerged from the study's findings that most respondents perceived social sciences as relevant and needed by the labour market because they facilitate a better understanding of human societies and their interactions (Goma, 1975, p. 8). The labour market (in)directly needs the culture, history, language, social interactions, and other behavioural patterns of people which can only be acquired in social science programs. Despite their general importance, the study found that there were different perceptions regarding the relevance of social sciences in contributing to the skills needs of the labour market compared to STEM programs. Besides, some correspondents considered social sciences as playing a secondary role to the labour market skills needs (Respondent P\#04): that is the key skills sit in the hard sciences and not social sciences. This perception of social sciences could have emanated from those (Yonezawa, 2017) who champion the debate on the knowledge divide between social sciences and physical sciences. Arguing that, unlike physical sciences, social sciences are generalist disciplines that do not give graduates specific skills and a clearly defined pathway (Kinash et al., 2016). This is except for fields such as Law and Economics that have clearly defined career pathways.

The negative perception of social science degree programs may have emanated from the belief that the use of any social science degree program can be defined by its immediate need to the skill requirements of the labour market and that anything short of that, renders such a program irrelevant together with the obtained qualification (Rastrick, 2018). The fact that STEM programs give graduates job-specific and applicable skills which is not the case with most social science degree programs, has led to the negative perception of social sciences being considered less useful. As factors espoused by the capability approach, the negative perception of social sciences is one of the social conversion factors created by employers within the labour sector. However, while social sciences degree programs are regarded as not having immediate relevance to the skills needs of the labour market, one would argue that they are important in many aspects. More so their relevance should not be questioned collectively but as independent disciplines.

\section{The demand for social science degree programs in selected universities}

The demand for social science degree programs in selected universities was noted to be a determinant of their relevance to the needed skills in Zambia's labour market. It emerged from the interviews that on average between 30 and 150 students were enrolled during the 2019 academic year. That is, not many students were enrolling for the social science degree (refer to respondents P\#07, P\#06, and P\#05). From the four-degree programs, more students were enrolled for the Bachelor of Social Work degree which indicates its popularity and signifies the demand for the qualification compared to others in the labour market (Singh, Themusamy, \& Ramly, 2014). This argument further supports the basis upon which the dwindling numbers of students enrolling in social science degree programs could be premised. Despite the declining numbers of students pursuing social science degree programs, the research on higher education in Zambia indicates that over $60 \%$ of university students pursued social science degree programs (Simukanga et al., 2020).

Although many universities in Zambia offer social science degree programs, the number of students registered in those degrees has been declining in the recent past. One possible explanation for this decline has been due to the limited job prospects for graduates from social sciences on the labour market (Finch, et al., 2013). Moreover, the direct and indirect costs associated with pursuing any of the four social science programs on self-sponsorship, and not public student financing, may have been another inhibiting factor for those who may want to access such programs (Mwelwa, 2014). This was the case following the Zambian government's shift in the student financing policy of 2018. It was biased and inclined to offer more student bursaries and loans to those who were enrolled for STEM 
degrees in public universities (Masaiti, Mwelwa, \& Mwale, 2015) in line with the national skills development agenda to achieve the vision 2030 (GRZ, 2006), as espoused by the human capital theory. It could be concluded that the Bachelor of Social Work graduates stood a better chance of being employed compared to those in the other three social science degrees.

In the subsequent section what constituted graduate employability in the four social science degree programs from the selected universities in Zambia is discussed in line with the second objective of this study.

\section{Perception of employability skills in social science degree programs}

Employability skills also known as generic skills, were found to be key in evaluating the relevance of the social science degree programs. Their levels of satisfaction with the acquired employability skills from the four social science degree programs by students and employer respondents were used to determine the relevance of the degree programs. The results showed both the students and employers rated their levels of satisfaction with the acquired employability skills differently. The ratings of eight employability skills were based on the 5-point Likert Scale. The employability skills included professionalism, accountability, ability to perform tasks in defined settings, selfmanagement, critical thinking, creativity and initiative skills, interpersonal skills, and problem-solving skills. It emerged that students were more satisfied (Mean score $=4.5$ ) with accountability skills compared to the other seven. They were least satisfied with problem-solving skills from their programs (Mean Score=4.2) (refer to Table 1.1). Students were least satisfied with the employability skills they acquired from social science degree programs. To the employers, all social science graduates who were rated on all eight employability skills obtained a score that was below 4.0 on the 5-point Likert scale. The employers, however, said they (graduates) were better equipped with problem-solving skills (Mean score $=3.6$ ) and professionalism skills (Mean score=3.5) (refer to Table 1). They were least satisfied with the graduate employees' interpersonal skills (Mean score $=3.2$ ).

The employability skills ratings by the students appear to be overrated compared to ratings by the employers on how they perceived their new graduate employees. The findings also show that employers were less satisfied with the accountability skills of their graduate employees. This is despite graduating students rating themselves highly on accountability. Both the student and employer ratings are key to understanding the role of employability skills in the question of the relevance of social science degree programs on the labour market. However, unlike the employer ratings of their graduate employees, the student ratings may not matter much to influence the perception by employers on the employability prospects of graduating students. The variations also point to a lack of uniformity and structure in the way employability skills were assessed and evaluated by the different universities and labour industry organisations (Hartman, 2014). For students, it could also mean a lack of a clear understanding of how such employability skills could be demonstrated once developed or acquired. For example, a poor score in interpersonal skills may mean that graduate employees experienced challenges in dealing and relating with new people in their newly found places of work. Moreover, the low self-ratings on their levels of satisfaction with problem-solving skills could mean that most students were truly less confident with their abilities to use rational and logical reasoning to arrive at appropriate conclusions in academic tasks (Riebe \& Jackson, 2014).

It emerged from the qualitative findings that there is a need for graduates to possess employability skills such as communication, analytical, interpersonal, creative thinking, and Information Communication Technology (ICT) skills. That is in line with Finch et al., (2013), Gao, Wang \& Cui, 2014) as well as Jackson (2016) who respectively concur that graduates need to possess employability skills for them to stand a better chance of being employed. Respondents were, however, uncertain on what constitutes the relevant mix of employability skills for one to be successful in the labour market. This is despite their being aware of the different sectors which may be unique in terms of employability skills varied from one employer to the other. Most respondents agreed that the way social science programs were taught had implications for the employability skills the graduates acquired. That means 
universities must teach what and how the employers want their prospective employees need to know. This is in line with Osmani et al., $(2019$, p. 1) who asserted that universities must empower students with relevant (self) employability skills to be analytical, critical, innovative, etc., as part of being workready.

\section{Social Science graduate work readiness}

The study noted that graduate work readiness was important for evaluating the relevance of social science degree programs for the skills needs in Zambia's labour market. Thus, the work readiness of final year university students was investigated in the four social science degree programs by conducting two statistical analyses tests, namely, the bivariate association (Table 2) and multivariate regression (Table 3). A quantitative method was adopted to analyse the age, gender, and programs of study as background characteristics and with varied findings. The latter were further corroborated and supported by the qualitative findings to determine graduate work readiness from social science degree programs.

Statistical analysis indicated that age was to be a factor in determining the work readiness of some final year students $(P=0.315)$ in the four social science degree programs (refer to Tables 2 and 3). It was established that the $35+$ years old students were more likely to be work-ready than those younger. Most of the unmarried students were not work-ready when they started their first jobs. Final year Bachelor of Development Studies students were noted to be more work-ready compared to those in the other three programs. The statistical analysis showed that there was an association between work readiness, age, and marital status. However, background information was found to be a less predictor of the association of student work readiness. It could be that the final year Bachelor of Development Studies students were more likely to be work-ready than others because they were married, older, and had the in-service component in their program (Tables 2 and 3). That could imply that the program had more students previously exposed to prior training and work experience (Gonzalez-Roma, Gamboa, \& Reiro, 2016). Such exposure gave students the opportunity of being work-ready in comparison to others with no prior experience. It could be concluded, based on the preceding statistical analysis, that most final year students who were in the four programs were not work-ready.

The interview findings corroborated the quantitative data that found students were not work-ready when they completed their qualifications. They were also not work-ready in their first-ever jobs and their productivity did not meet the expectations of their employers. The preceding discussion indicates the importance of work readiness which inter alia entails the ability for graduates to demonstrate essential competencies and attributes at the level of job entry (Rowe \& Zegwaard, 2017). That means being not work-ready, in this context, refers to graduates who don't possess the required skills at the time of securing a job (Gonzalez-Roma et al., 2016). Although being work-ready or not is relative and depends on the prospective employers' perception, it was possible that some graduates were not work-ready because they missed or were not exposed to quality work-integrated learning activities such as internships to acquire employability skills (Singh, Thambusamy, \& Ramly, 2014). This finding also adds to the unperceived existential mismatch between the university outcomes on skills development and the skills labour markets expect graduates to have in Zambia (Moono \& Rankin, 2013).

\section{Availability of graduate job prospects}

The availability of graduate job prospects emerged from the findings as one of the key themes which influenced the employability of social science graduates from the four programs. Findings from both the quantitative and qualitative data revealed that graduates from the four social science degree programs had different employability prospects. It is indisputable that the latter was used to determine graduate employability with relevant programs in the labour market. That was endorsed 
by the many social science graduates who preferred to be employed after completing their degrees (refer to Table 4) compared to those who opted for either self-employment or to pursue further studies. This implied that the underlying motive for most of the students who participated in the study was to secure jobs. For example, most students pursued teaching degrees in social science so that they can be employed after graduation. Their reasons could be due to limited job opportunities in either the public sector or self-employment areas. Table 4 indicates that $25 \%$ of Social Work students stood higher employment chances in the private sector compared to those studying in other programs. This also entailed relevant knowledge and skills students acquired from the social work program in Zambia's both public and private sectors. Most Bachelor of Public Administration program (42.9\%) students pursue further studies after graduation. That indicated their assumption for better employment opportunities with postgraduate degrees.

The preceding findings further indicate variations in the availability of employment opportunities from the social science qualifications in the labour market. For example, Bachelor of Social Work graduates had higher chances of employability compared to other social science graduates (refer to Table 4). On the other hand, Public Administration, Development Studies, and Education (social science) graduates had limited job opportunities. That may be because they do not match Zambia's labour market needs and are thus not a priority (MOHE, 2019). Besides, Zambia's labour market was saturated with social science graduates, unlike STEM graduates.

The question of limited job prospects for graduates from social science degree programs could further be explained in the context of the Capability Approach (Pandolfini \& Poli, 2015). For instance, the negative value perception of qualifications obtained from any of the social science programs could be due to the social conversion factors as espoused by the Capability Approach. These factors may entail that potential employers could be questioning the quality of qualifications obtained from all four social science degree programs and the extent to which they limited the graduates' capabilities and agency to pursue careers they chose (Robeyns, 2005; Clarke, 2018a). Additionally, in the context of the screening hypothesis, (Page, 2010) an impression could have been created that the qualifications from the social science degree programs were screened to be of less value or no immediate relevance and thereby exposing such graduates to limited job prospects (Akinyemi, 2013). It could be concluded from the preceding discussion that job prospects of Education, Public Administration, and Development Studies graduates were more limited than those of Social Work graduates.

\section{Conclusion and implications}

It can be concluded that the discourse surrounding the relevance of the four social science degree programs to employability skills development is complex and multi-faceted. Every social science degree program is unique and equips graduates with skills that are relevant in their ways and vary according to the needs of the labour market. Although all social science programs are important, this article has established that the Bachelor of Social Work seemed to be more relevant and appealing to the labour market skill needs than the other three programs. The skills acquired by the Social Work graduates were more in demand especially by the local and international organisations concerned with social empowerment programs in Zambia. That put Social Work graduates at an advantage of higher job prospects than the other social science graduates. The relevance of the other three programs was diminished due to the low demand for them in the labour market. The relevance of each of the four social science degree programs depended on the prospective employer's perception of their usefulness in their organizations. They decided on the qualification as well as the skills of the graduates they wanted. These facilitated graduates to either secure employment or employ themselves. Summarily, the four social science degree programs were to some extent less effective in promoting skills development amongst graduating students. As such, they were generally not very relevant to the immediate skill needs in the labour market.

This study also brings to the fore several implications. Human Capability Theory was used to explore the extent to which the social science degree programs were relevant in promoting skills development

Mwelwa, K., Lebeloane, L.D.M., \& Mawela, A.S. (2021). Relevance of Selected Social Science Degree Programs on Skills Development and 
and graduate employability in Zambia. This is one of the few empirical studies conducted in the Zambian context to illuminate how skills development and graduate employability could be promoted in social science degree programs offered by universities. The conclusion that promoting graduate employability in the four social science degree programs is both complex and multifaceted calls for a multi-stakeholder approach in which the academia, the labour industries, and policymakers must collaborate to enhance graduate employability outcomes. It is also implied that universities that offer social science degree programs must provide a clear articulation of the program knowledge and skills outcomes for all program courses on offer. In terms of practice, the methods of teaching in social science degree program courses must encompass and promote the acquisition of such competencies as clearly set out in the national qualification framework. Capacity must be built in academia by equipping lecturers with the pedagogical knowledge and skills on how employability skills in social sciences can effectively be integrated into the curriculum, taught, developed, and evaluated without overemphasising the disciplinary knowledge. More so, seeing that employability opportunities are easy to come by for graduates from STEM and Business-related programs, universities may consider rethinking the interdisciplinary approach by strategically integrating some STEM and Business courses into social science degree programs, as a smart way of enhancing the acquisition of both the technical and generic (employability) skills by those who pursue social science degree programs.

\section{Limitations and directions for future research}

The inability of the researchers to use a sample larger than 162 participants was one of the limitations of the study. The outbreak of COVID-19 in Zambia in March of the year 2020 led to the abrupt closure of all higher learning institutions. The closure coincided with and negatively affected the data collection exercise from university students both in terms of their availability and retention of already distributed questionnaires. The use of other non-contact online means of data collection hindered the researchers to reach the expected number of students due to poor and limited internet connectivity in most parts of the country. Despite its size, the selected sample was representative, and researchers ensured that data were collected and analysed rigorously to ensure validity and reliability. Based on the above-mentioned reasons, caution must, however, be exercised to avoid express generalisation of the results to all social science degree programs offered by universities in Zambia. For future research, an investigation may be conducted on how student internships should be designed and implemented by universities and labour market organisations to promote the acquisition of employability skills in social science degree programs in Zambia.

\section{References}

Akinyemi, S. (2013). The economics of education. Houston: Strategic Publishing and Rights Co.

Anwaruddin, R.M. (2013). Neoliberal universities and the education of arts, humanities and social sciences in Bangladesh. Policy Futures in Education, 11(4), 364-374

Axelrod, P. (2017). Is there too much emphasis on STEM fields at universities? Canada: York University. Available at: https://theconversation.com/is-there-too-much-emphasis-on-stem-fields-at-universities$\underline{86526}$

Bhorat, H., Cassin, A., Masumba, G., Naidoo, K., \& Steenkamp, F. (2015). Youth unemployment challenges in Zambia: A statistical profile, current policy frameworks, and existing interventions. Ottawa: International Development Research Centre.

Bless, C., Higson-Smith, C., \& Sithole, S.L. (2013). Fundamentals of social research methods: An African perspective, $5^{\text {th }}$ Edition. Cape Town: Juta and Company.

Bryman, A. (2008). Social Research Methods. Oxford: Oxford University Press.

Clarke, M. (2018a). Rethinking graduate employability: The role of capital, individual attributes and context. Studies in Higher Education, 43(11), 1923-1937. DOI: 10.1080/03075079.1294152

Clarke, M. (2018b). Understanding and managing employability to changing career contexts. Journal of European Industrial Training, 32(4), 258-284.

Cohen, L., Manion, L., \& Morrison, K. (2010). Research methods in education. New York: Routledge. 
Creswell, J.W. (2014). Research designs: Quantitative, qualitative, and mixed methods approaches, $\left(4^{\text {th }}\right.$ Ed.). Thousand Oaks, CA: Sage.

Creswell, J.W., \& Plano Clark, V.L. (2007). Designing and conducting mixed methods research. Thousand Oaks, CA: Sage.

Cunningham, W.V., \& Villaseñor, P. (2016). Employer voices, employer demands, and implications for public skills development policy connecting the labour and education sectors. The World Bank Research Observer, 31(1), 102-134.

Damoah, O.O., Peprah, A.A., \& Brefo, K.O. (2021). Does higher education equip graduates with skills employers require? The perceptions of employers in Ghana. Journal of Further and Higher Education. DOI: 10. 1080/0309877x.2020.1860204.

ElKhayat, R.S. (2018). The capabilities approach: A future alternative to neoliberal higher education in the Mena Region. International Journal of Higher Education, 7(3), 36-44.

Field, A. (2013). Discovering statistics using IBM SPSS Statistics, $\left(4^{\text {th }}\right.$ ed.). Thousand Oaks, CA: Sage

Finch, D.F., Hamilton, L.K., Riley, B., \& Zehner, M. (2013). An explanation of factors affecting undergraduate employability. Education and Training, 55(7), 670-681.

Flash Eurobarometer (Eu). 2010. Employer's perception of graduate employability: Analytical Report. Available at: https://op.europa.eu/en/publication-detail/-/publication/198872b7-1dff-47a7-954c-f27e0115fd5b

Gao, L., Wang, X., \& Cui, Y-P. (2014). Courses and employability skills: The voice of students. Proceedings of the 2014 International Conference on Management Science and Management Innovation, Atlantis Press. P.43-49. https://dx.doi.org/10.2991/msmi-14.2014.8

Goma, L.K.H. (1975). The African university and the human understanding: Vice-Chancellors speech at the seventh graduation ceremony of the University of Zambia.http://saipar.org/wpcontent/uploads/2013/10/Goma-Speech.pdf

Gonzalez-Roma, V., Gamboa, J.P., \& Peiro, J.M. (2016). University graduates' employability, employment status, and job quality. Journal of Career Development, 45(2), 132-149.

Government of the Republic of Zambia (GRZ). (2006). Zambia Vision 2030. Lusaka: Ministry of Finance and National Planning. Available at: https://www.mndp.gov.zm/wpcontent/uploads/filebase/vision 2030/Vision-2030.pdf

Government of the Republic of Zambia. (GRZ). (2015). National Youth Policy: Towards a Skilled Enlightened, Empowered and Patriotic Youth impacting positively on National Development. Lusaka: Ministry of Youth and Sport. Available at: https://www.ilo.org/wcmsp5/groups/public/---ed emp/--ed_emp msu/documents/projectdocumentation/wcms 427020.pdf

Hartman, J.L. (2014). Internships. In J.S. Albanese (Ed.). The encyclopaedia of criminology and criminal justice (pp.1-4), Fifth Edition. New York: John Wiley and Sons.

Igwe, P.A; Lock, D \& Rugara, D.G. (2020). What factors determine the Development of Employability Skills in Nigerian Higher Education? Innovations in Education and Teaching International. DOI: 10.10.80/14703297.2020.1850319

Jackson, D. (2015). Employability skills development in work-integrated learning: Barriers and best practices. Journal of Studies in Higher Education, 40(2), 350-367.

Jackson, D. (2016). Skill mastery and the formulation of graduate identity in bachelor graduates: Evidence from Australia. Journal of Studies in Higher Education, 41(7), 1313-1332.

James, S., Warhurst, C., Tholen, G., \& Commander, J. (2013). What we know and what we need to know about graduate skills. Work, Employment and Society, 27(6), 952-963.

Kinash, S., Crane, I., \& Judd, M.M. (2016). Good Practice Report: Nurturing Graduate Employability in Higher Education. Sydney: Australian Government Office for Learning and Teaching.

Legg, C., \& Christopher, H. (2021). 'Pragmatism'. In Edward N. Zalta (Ed.), The Stanford Encyclopedia of Philosophy (Summer, 2021 Edition), forthcoming URL: https://plato.stanford.edu/archives/sum2021/entries/pragmatism/

Masaiti, G., Mwelwa, K., \& Mwale, N. (2015). Shifting from government bursaries to a loan scheme in higher education: Exploring the Zambian experience in student financial Aid. International Journal of African Higher Education, 2, 69-99.

Menashy, F. (2014). Theorising privatization in education: Comparing conceptual frameworks and the value of the capability approach. Current Issues in Comparative Education, 16(1), 13-25.

Ministry of General Education [Zambia]. (2017). 2016 Educational Statistical Bulletin. Lusaka: Ministry of General Education.

Ministry of Higher Education. (2019). National Higher Education Policy. Lusaka: Ministry of Higher Education. Ministry of Higher Education. (2019). National Higher Education. MOHE, Lusaka. 
Moono, H., \& Rankin, N. (2013). Education and employment in Zambia: Evidence from a scoping exercise. International Growth Centre, Stellenbosch University.

Morgan, D. I. (2007). Paradigms lost and paradigms regained. Journal of Mixed-methods Research, 1(1), 48-76.

Mulenga, I.M. (2015). English language teacher education curriculum designing: A mixed-methods analysis of the degree program at the University of Zambia. Unpublished Doctoral Thesis, University of Zambia, Lusaka.

Mwelwa, K. (2014). Implementation of the student loans scheme policy as a viable cost-sharing measure in promoting equitable access to higher education in Zambia. Perspectives of Selected Stakeholders in Education. Unpublished Masters Dissertation, University of Zambia, Lusaka.

Mwila, K. (2017). Education and skills development: Examining the effectiveness of technical education, vocational and entrepreneurship training in Solwezi District of Zambia. Unpublished Masters Dissertation, University of Zambia, Lusaka.

Onwuegbuzie, A.J., \& Combs, J.P. (2011). Data analysis in mixed research: A primer. International Journal of Education, 3(1), 1-25.

Oppong, S., \& Sachs, P.R. (2015). Managing graduate employability in emerging economies: Critical analysis of the skills mismatch and oversupply theses. Business Excellence, 9(1), 125-137.

Osmani, M., Weerakody, V., Hindi, N., \& Eldabi, T. (2019). Graduate employability skills: A review of literature against market demand. Journal of Education and Business, 94(7), 423-432.

Page, M.E. (2010). Signaling in the labour market. In D.J. Brewer \& P.J. McEwan, (Eds.). Economics of Education, (pp.33-36). New York: Elsevier.

Pandolfini, V. \& Poli, S. (2015). Education as a capability for young adults' life trajectories: Some evidence from an Italian case study. Italian Journal of Sociology of Education, 7(2), 43-69.

Rastrick, C. (2018). Meaningful employment for humanities and social sciences graduates. Ontario: Ontario Centre for Workforce Innovation.

Riebe, L., \& Jackson, D. (2014). The use of rubrics in benchmarking and assessing employability skills. Journal of Management Education. 38(3), 319-344.

Robeyns, I. (2005). The capability approach: A theoretical survey. Journal of Human Development, 6(1), 93114.

Rowe, A.D., \& Zegwaard, K.N. (2017). Developing graduate employability skills and attributes: Curriculum enhancement through work integrated learning. Asia Pacific Journal of Cooperative Education, Special Issue, 18(2), 87-99.

Shenton, A.K. (2004). Strategies for ensuring trustworthiness in qualitative research projects. Journal of Education for Information, 22(2), 63-75.

Simukanga, S., Chifwepa, V; Mfune, O., Nsokolo, D., \& Chanda, D. (2020). The State of Higher Education in Zambia 2019: 5 Decades of University Education. Lusaka: Higher Education Authority. Available at: https://hea.org.zm/wp-content/uploads/2020/11/The-State-of-Higher-Education-in-Zambia-2019.pdf

Simukungwe-Moono, M. (2010). Program development and employability in higher education institutions in Zambia. Unpublished Masters Dissertation, Oslo University, Norway.

Singh, P., Themusamy, R.X., \& Ramly, A. (2014). Assessing graduate's generic skills: An indicator of employability. Pertanika Journal of Social Sciences and Humanities, 22(3), 845-860.

Tavakol, M., \& Dennick, R. (2011). Making sense of Cronbach's Alpha. International Journal of Medical Education, 2, 53-55.

Teddlie, C. \& Tashakkori, A. (2009). Foundations of Mixed Methods Research: Integrating Qualitative and Quantitative Approaches in the Social and Behavioural Sciences. Thousand Oaks, CA: Sage.

United Nations Development Program (UNDP). (2016). Zambia Human Development Report 2016: Industrialisation and Human Development. Lusaka: UNDP.

University of South Africa (UNISA). (2016). Policy on Research Ethics. www.unisa.ac.za

Yonezawa, A. (2017). The Humanities and Social Sciences in the Age of STEM: The Struggle of Japanese as a Linguistic Minority. International Higher Education. 88, 31-33.

Zambia Statistical Agency. (2019). Zambia 2019 Labour Force Survey. Lusaka: Zambia Statistical Office. 